\title{
Multiplication of Negative Scenarios: the Approach Public Administrations Could Use at Drafting General Rules
}

\author{
Mirko Pečarič \\ University of Ljubljana, Faculty of Public Administration, Slovenia \\ mirko.pecaric@fu.uni-lj.si \\ https://orcid.org/0000-0002-0551-5682
}

Received: 17. 12. 2018

Accepted: 18. 2. 2019

\section{ABSTRACT}

This paper addresses problems that emerge when draft laws are created without due regard for the calculus of probability. Although the latter should be sine qua non for future legislation, legislators usually do not use it despite the legislation's pro future orientation. The paper, based on Hume's old "is-ought" problem (the impossibility to move from descriptive statements to prescriptive ones) and with the awareness that probability will not be used soon, offers a solution for the future legislation in the multiplication of (negative) scenarios, applied to different life questions. Despite the more and more "popular use" of regulatory impact assessments, smart regulation, probability and risk, public administrations as the major drafters of general legal rules usually do not even use the (much simpler) negative approach to gain better insight into problems, although it is per se the natural way of our thinking. A new view on probability through signs that fit into (unwanted, but known in advance) scenarios can also provide new answers regarding causality. The latter is based on signs, which is what evidence per se really means.

Keywords: apophatic (negative) decision-making, draft legislation and regulation, probability

$J E L: K 40$

\section{Introduction}

Authorities have no "authority" over the natural laws and - as practice shows - only moderate over people's emotions and actions. The understanding of (un)related (legal) effects nevertheless became more possible with the first publications of empirical data on deviancy by government bodies, when de- 
terminism was subverted by the laws of chance. ${ }^{1}$ A first step towards better understanding of such laws is in recognition that legal rules are always (intuitively) weighted (Brest and Krieger, 2010; Dworkin, 1978; Irving John Good, 1983), balanced and more or less probable (the latter is seen in the evidentiary standards like "beyond reasonable doubt, probable cause, sufficient cause, necessary cause"). For Cicero, probability (P) was the very guide of life (2008) and this ipso facto - and even more than for past cases - holds for each decision that should be applied in the future. The latter comes thus relevant also for rule-making that affects a larger number of people than adjudication. Although as a lawyer Leibniz already understood $P$ as a part of natural jurisprudence as degrees of assent, of perfection, of likelihood or the chain of evidence (G. W. Leibniz, 1988; G. W. F. von Leibniz, 1996), P somehow bypassed the later generations of lawyers. There is much literature about responsive (Ayres and Braithwaite, 1995), smart (Gunningham, Grabosky and Sinclair, 1998), meta (Chiu, 2015), risk-based (Black, 2012) and other forms of regulation, while $P$ is still rarely mentioned (let alone used in the public administration as the largest governmental drafter of general legal rules), although scholars debate about it for more than 45 years (Ayres and Nalebuff, 2015; Finkelstein and Fairley, 1970, 1971; Tribe, 1971). There is a large number of countries that nowadays address regulatory issues within the impact assessment context (to enhance regulatory legitimacy and accountability) (OECD, $2009,2014,2017)$, but they should go deeper into the very core of $P$ to have better laws, to make decisions with more predictable results.

The paper's predisposition is that $P$ has not been sufficiently elaborated in legal drafting, although it is engraved in the very foundations of decisionmaking, in degrees of belief, in indications as inartificial proofs and analogy between legal cases and notions (Beecher-Monas, 2007; Brest and Krieger, 2010; Dwyer, 2008). The basic connection between $P$ and evidence comes from the very etymological grounds of "evidence" as "the ground for belief or an indication or sign" ('Evidence | Define Evidence at Dictionary.com', 2016) that 'tends to prove or disprove the existence of an alleged fact' (Garner, 2004, p. 595). ${ }^{2}$ And a sign is recognised as such through the order and connection of ideas (to change the order and connection of things and vice versa) (Descartes, Spinoza and Leibniz, 1974). In P's core are not complex causations, but changing (subjective) perspectives from which signs are recognised as probable evidence, not only in the law, but in all matters. There are no special forms of reasoning peculiar to law (Alexander and Sherwin, 2008); lawyers engage in the same modes of (intuitive, logical) reasoning as other people do. Quality in regulation emanates from behaviour (Ridder, 2007); the common thought, tradition, institution, and even reason are repetitive forms of behaviour, but the public administrations should not only describe/recognise what is happening (there are plenty descriptive models of reality for example the

1 To believe there were such laws, one needed law-like statistical regularities in large populations. How else could a civilisation hooked on universal causality get the idea of some alternative kind of law of nature or social behaviour (Hacking, 1990, p. 3)?

2 Probability is simply the appearance of connections, resting on proofs [here = "lines of thought'] in which no logical connection is seen (G. W. F. von Leibniz, 1996, p. 232). 
Weberian, New Public Management, Neo-Weberian, Governance and Good administration model), but to look ahead, in the future, a new approach is needed. A next step is to predict what could happen (in a manner of driving a car - by looking mainly straight ahead, not backwards). If we paraphrase Marx's saying on philosophers, also decision-makers have mainly 'interpreted the world in various ways; the point, however, is to change it' (Marx, 1976, p. 574). And this stands also in the field of legal probability; ${ }^{3}$ legislators enact laws also without knowing their potential (side) effects (Merton, 1936; Sieber, 1981) or from the standpoint of classical perspectives.

So, how things can be changed in the future from the present standpoint, and not only described? If there is a difference between the descriptive and prescriptive laws, why is so hard to recognise the natural and complex (descriptive) things cannot be regulated prescriptively (the law can merely more or less accommodate to natural things)? The classical regulatory methods that are in their core still in the past centuries ${ }^{4}$ - are not good enough, because they do not imitate complex adaptable organisms that can adapt to the flexible environment. A personal adaptation is the subjective element of recognition to adapt, but also this phase is based on a pre-step connected with a way by which information is collected, and also the latter is recognised as such through the numerous receptors. And the same could stand for the public administrations as regulators. This paper is focused on legal drafting that receives too little attention in connection with $P$, because the laws and regulations affect a larger number of people than adjudications, and more empirical data is available to form a prior $P$ or base rate on which relevant general decisions can be made. One of the major obstacles for a higher level of objectivity at general drafting is the apparent logical impossibility of the principle of induction to form general statements - known as Hume's guillotine or fact-value gap (Hume, 2009). Findings on the inductive method affect human rights and their universal and inalienable nature, so better understanding of it is not only sine qua non for understanding of $P$ but also of legislation/regulation. Nobel prizes have been given for works on human bias and fallibility, but public servants still mainly prepare draft rules with the help of their common

3 One of the rare examples of probability is the so-called precautionary principle, in the EU law applied in the field of environment (see Article 191(2)). One of the most-known cases from this field is the judgment of the Court of First Instance, T-13/99, Pfizer Animal Health SA v Council of the European Union [2002]. About the apportionment of the burden of proof, the court stated that 'the Community institutions must show, first, that the contested regulation was adopted following as thorough a scientific risk assessment as possible, which took account of the particular circumstances of the present case, and, second, that they had available, on the basis of that assessment, sufficient scientific indications to conclude, on an objective scientific basis, that the use of virginiamycin as a growth promoter constituted a risk to human health' (рага 164). Despite the fact that institutions enjoy a discretion vis-a-vis the pursued objectives and appropriate means of action, the level of risk and/or the severity of the impact on human health and the probability of possible adverse effects, should still be based on "available scientific knowledge« (para 152). But - but what to do when on some (legal) field there is no scientific knowledge on probability that would allow predictions (that is legal decisions)? In this case public officials should create it themselves, and/or at least understand some basis of P.

4 A reader could compare a newest statute of his country with the General State Laws for the Prussian States (Allgemeines Landrecht für die Preußischen Staaten) of 1794, and search for differences. 
sense and/or intuition (of what would be the right thing to do or enact), in a way laws were made centuries ago. The paper's RQ is:

How $P$ can be embedded in legislation and regulation, and how the public administrations could be more adaptable to changes in environment and be at the same time in accordance with public values?

\section{The paper's predispositions}

One of the first obstacles to make legislative drafting more efficient is confirmation bias, as a deliberate and exclusive search for confirming evidence. ${ }^{5}$ This kind of cognitive ease with attention focused only on the personal, visible or accessible parts is not only very known - think on Rawls's veil of ignorance (2005) - but it is still blind (that further confirms it as bias) to other individual cases that disconfirm them. It is also a negative companion to public and/or collective decision making. Because of its prevalence also in legislative drafting (a parliamentarian coalition rarely accepts oppositions arguments), it will be further addressed later in the paper. The paper claims more objective criteria could be established to draft general laws, because reality does not matter for coalitions in Parliaments and happens through things capable to act based on numerous (un)intended causes and effects. Decision-makers can enact better legislation/regulation if they recognise $P$ (and with this a basic unpredictability) as a major player in decision-making; their decisions could be - through the insertion of P-procedures as the numerical degrees of belief - more predictable, thorough and more objective. If this is too optimistic, decision-makers could at least be aware changes in the flexible environment are happening more often than classical legal rules "permit".

The second obstable is classical causality or the cause-effect relation, although already Carnap in 1966 claimed causality 'is not a thing that causes an event, but a process... [in which] certain processes or events cause other processes or events' (Carnap, 1966, p. 190). Cziko describes this as circular causality, where 'perceptions do not control behaviour. Rather, individuals vary their behaviour as necessary to control their perceptions and thereby obtain desired outcomes and avoid unwanted ones' (2000, p. 253). Circular causality (feedback loops) is one of the main elements of systems theory, and it can give different perspective also for legislation by bypassing the »is-ought" problem.

An effective application of mathematical $P$ will probably not be used any time soon in the practice of legal drafting, so to be fast and pragmatic at the same time, a method used in apophatic (negative) theology is proposed for the public administrations: decisions about future results could be closer to goals

5 Although this bias has become better known through the works of Tversky and Kahneman (2013; 1974), it is found already in cataphatic theology, in which knowledge of God is obtained through defining God with positive statements (Oxford Dictionaries, 2016). This tendency can also be found in scholars' papers where authors - if they want to gain a reviewer's attention cite numerous authors at the beginning of their papers that have focussed their efforts on a particular problem, while falsifiability is ignorant for them; it is based only on experience. 
when decision-makers know what results they do not want, what is absent in the present state of things. Such general decisions cannot be the sharp sword of Alexander to cut a hard knot of unpredictability, but they can be sharp enough - if (besides the mathematical $P$ ) negative exclusion and the signs of evidence (which decision-makers possess) are used with $P$. To reach this aim, the problem of legal induction will be described in the next chapter, to be able to propose a way of determination of $P$, i.e. beliefs in legal drafting in the fourth chapter. In the fifth chapter, a problem of "legal cosmology" will be described in order to offer a solution to this problem. The paper's predispositions are the existence of confirmation bias that could be minimised with the application of $P$, within the frame of circular causality. As $P$ will probably not be used in the law in a manner used in natural science, a "shortcut" will be given in a form of negative thinking.

\section{The problem of legal induction in the absence of causality}

For Comte 'the positive point of departure for the work of the statesman ... [is] to discover and institute the practical forms to avoid...crises which spontaneous development brings about when it has not been foreseen...in this order of phenomena science leads to foresight, and foresight allows us to regulate action' (1998, p. 3). Although this sentence - usually known as savoir pour prevoir, prevoir pour pouvoir (to know in order to predict, to predict in order to control) "sounds nice", it jumps to the conclusion because methods of knowing and understanding are accepted as relevant also without being tested first. As all of them address reality from the inductive or deductive point of view, it is valuable to readdress Hume's is-ought problem. ${ }^{6}$ Hume represents the beginning of the still unfinished conception of science that was/is based on the inductive method of research. It is the same as a conditional form of the legal norm (if $\rightarrow$ then), and is thus important also for legislators. Kant has tried to avoid Hume's critique of the principle of causality (phenomena) by declaring pure concepts as a synthetic a priori principles as things in themselves (noumena): 'this complete solution of the Humean problem... restores to the pure concepts of the understanding their a priori origin... not, however, in such a way that they are derived from experience, but that experience is derived from them, a completely reversed type of connection that never occurred to Hume' (2004, pp. 64-65). Sir Karl Popper agreed with Kant we must confront the nature with hypotheses and demand a reply to our questions, but Kant's a priori valid expectation proved too much for him; 'in thinking that these laws are necessarily true, or that we necessarily succeed in imposing them upon nature, he was wrong. Nature very often resists quite

6 For Hume, induction cannot be logically defensible, while causes and effects can be discovered by experience (not by reason): 'even after the observation of the frequent or constant conjunction of objects, we have no reason to draw any inference concerning any object beyond those of which we have had experience' (Hume, 2009, p. 228). For him, all reasoning about facts originates from the cause-effect relation, although we have no coherent understanding of causality: 'the sense of justice is not founded on our ideas, but on our impressions... [which] are not natural to the mind of man, but arise from artifice and human conventions' (Hume, 2009, p. 757). 
successfully, forcing us to discard our laws as refuted; but if we live we may try again' (1962, p. 48). ${ }^{7}$ Although Popper agreed with Hume's denial of the logical justification of the principle of induction, he was dissatisfied with his psychological explanation of induction in terms of custom, because observations 'аге repetitions only from a certain point of view' (1962, p. 46). ${ }^{8}$ Instead of explaining our propensity to expect regularities as the result of repetition, Popper proposed explaining repetition-for-us as the result of our "propensity to expect" and search for regularities to solve our problems; he invites us to provide new hypotheses (expected regularities and/or patterns) through which we could evaluate their refutability by real facts that emerge under the trial and error principle.

How can legislators/regulators overcome Hume's guillotine, Kant's a priori principles and Popper's propensity to expect? Decision-makers many times still (only intuitively or also logically) "feel right" i.e. when they use common sense and intuition as the prime movers of general rules when they do/enact something (Вaron, 1998; Kahneman, 2013), but they should also take into account possible future »detours " of their acts. One way to bridge a gap between a legal act and different effects in the future is to consider Wittgenstein's language games: he rejected the (apparent) paradox of following and breaking the rule ${ }^{9}$ by treating action in accord with the rule as its practice: "there is a way of grasping a rule which is not an interpretation, but which is exhibited in what we call "obeying the rule" and "going against it" in actual cases...And hence also "obeying a rule" is a practice" (Wittgenstein, 1986, p. 81). A connexion between what humans say/read/understand as a rule and their actions must thus be regular enough to call it "language", "institution" or "the law". A rule is thus what its practice shows. Where rules are stated prescriptively ('woman do not enter rum shops') much depends on how people stand to a rule with which their conduct conforms (Maclntyre, 1978, p. 220). Rules' meanings are established with their practical usage.

A next step is a link between future practices and (prescriptive) legislation that can be established with imagined practices (scenarios) without using causality (the latter cannot be even present in draft laws as they are focused in the future). Actions are made/recognised as such in our mental frames, where general statements are required by our mind in the form of our inborn

7 The scientific method depends on considering at the outset the hypothesis that variations in the data is completely random and modifying it step by step as data is found to support alternatives is a complete reversal of the nature of induction as understood by philosophers (Jeffreys, 1998, p. viii).

8 Similarity-for-us is the product of a response involving interpretations (which may be inadequate) and anticipations or expectations (which may never be fulfilled). It is therefore impossible to explain anticipations or expectations as resulting from many repetitions, as suggested by Hume. For even the first repetition-for-us must be based upon similarity-for-us, and therefore upon expectations - precisely the kind of thing we wished to explain. This shows that there is an infinite regress involved in Hume's psychological theory (K. R. Popper, 1962, p. 45).

9 No course of action could be determined by a rule, because every course of action can be made out to accord with the rule... if everything can be made out to accord with the rule, then it can also be made out to conflict with it. And so there would be neither accord nor conflict here (Wittgenstein, 1986, p. 81). 
propensity to look for regularities/similarities. This propensity can be a bridge between is and ought, if causality is left outside of the is-ought problem. All observation involves the recognition of dis/similarities; this recognition, although psychologically and logically a priori, is not valid a priori, for our recognition may fail in new environments, where we often fail to find regularities. Order is established ex automata if it is suitable for a relevant legal context. Despite the logical impossibility of the principle of induction to climb on a ladder of generality, there is our psychological a priori search for regularity. A psychological a priori drive or search for regularity to embrace uncertainty is not the solution for the "is-ought" problem but it can be the explanation for our actions. The mentioned problem can be more objectively addressed (but not solved) in the field of $P$ that accepts ought as merely probable based on the past data. Hume's statement was often erroneously understood as a statement making no claims about what ought to be a basis of a statement about what is. Claims can be made; although they are not valid logically, they are "good enough" for the ordinary course of things. If this is not true, legislators could not enact laws as general rules in which ideas and values have no real existence, but exist only as the object of feeling, of values not of reason: '[s]elf-interest is the original motive for the establishment of justice: but sympathy with public interest is the source of the moral approbation, which attends that virtue' (Hume, 2009, p. 762). Our natural tendency for order could on the practical level bypass Hume's problem; it gives us a foresight that enables us to regulate our actions. The human inborn tendency for order and the search for missing things brought us to the very gates of $P$, which resembles to the doorkeeper's answer in Kafka's novel The Trial (2004): "[n]o one else could ever be admitted here, since this gate was made only for you. I am now going to shut it". The gates are open, and we should step in to grasp $P$.

\section{Probability in the law}

In numerous legal works, $P$ is not even mentioned. In some it is, but how it can be estimated is not presented (Hood, Rothstein and Baldwin, 2001; Hudson, 2003; Palmer, 1998) or it is done very briefly (Dwyer, 2008; Fisher, 2012; Palmer, 1998), intended to be applicable for usual legislators or public servants as the major drafters of statutes (not being neither experts, nor even beginners). Ordinary logic seems to be inadequate in itself to cope with problems involving beliefs (think about a legal promise or future obligation where inference cannot be made from a particular case to all future cases), so a theory of $P$ has been developed. What and how should a decision-maker consider different elements to regulate future events? $P$ is a central concept of everyday decision-making (think about it the next time you cross a street in traffic without a traffic light), although maybe due to the principle of legal certainty and "predictability" (sic) something that is only probably (although sine qua non of each future event) is not very appreciated at legal drafting. We do conclusions intuitively (in our lives and mainly also at legal drafting); since we do not obtain Ps through statistical methods assumptions can be overestimated. In the US, the Supreme Court, in the case Daubert v. Merrell Dow Pharmaceu- 
ticals, Inc. 509 U.S. 579 (1993), developed a methodology for these kinds of questions. In this case, the Court demanded the trial court not only has the power but also the obligation to act as a gatekeeper in determining whether an expert's opinion is based on scientific reasoning ${ }^{10}$ and methodology. The Court gave a non-exclusive list of four factors (that assist to answer a question if reasoning or an approach can be scientifically endorsed and used for the facts at issue): 'including whether the theory or technique in question can be (and has been) tested, whether it has been subjected to peer review and publication, its known or potential error rate, the existence and maintenance of standards controlling its operation, and whether it has attracted widespread acceptance within a relevant scientific community' (at 12-15). It is also of the utmost importance for the public servant to know how people's beliefs and evidence are transformed into decisions.

Judges are not supposed to take previous convictions into account, while legal drafters must take the past and present problems into account. It is surprising that $P$ is not used very often in legislation/regulation due to its known procedures that help us to think equally in equal situations, i.e. to reduce subjectivity (bias) to a minimum. There is no claim that reasonable beliefs can be measured, but relations between them can be calculated. ${ }^{11} P$ does not concern the merits of the case but the (more objective) regulation of procedure. It would be useful if a higher degree of objectivity is present in legal reasoning; this is possible when $P$ is used. $P$ was/is a feature of the legal history and is still a part of existing legal systems if decision-makers admit this or not. The same applies for the distinction between the factual and legal state of affairs. Although each decision maker should be acknowledged with conditional probabilities or natural frequencies (Carrier, 2012; Edwards, Jr and Winterfeldt, 2007; Gigerenzer, 2003; Gigerenzer, Todd and Group, 2000; Hacking, 2001), we will not go into the details of $P$ here. As was already mentioned in the second chapter one method to get closer to predict future actions more easily will present $P$ 's very beginning. It lies in the search for consequences, although not in the usual way. They can be established by looking for the opposites of everything decision-makers know.

\section{A problem of "legal cosmology"}

As cosmology is the scientific study of the large scale properties of the universe as a whole, in the same manner legal science naivelly tries to legislate/

10 One of the first decisions where the US Supreme court used social science in support of its decision was Brown v. Board of Education of Topeka, 347 U.S. 483 (1954); in this case, the court used seven social works from different authors (see note 11 of the decision) to claim that the segregation of white and coloured children in public schools has a detrimental effect on the coloured children.

11 A probability theory, being a fixed procedure, lends a certain amount of objectivity to your subjective beliefs (I. J. Good, 1950, p. 4). The probability you assign to any particular proposition is a matter for your own personal judgement, but the set of all your probability assignments is subject to fairly strong rules of internal coherence (Hacking, 2006, p. 14). 
regulate society as a whole. ${ }^{12}$ But as the first uses $\mathrm{P}$ in its operations, the second lag behind. A problem of »legal cosmology« is hence made by prediction without using P. ${ }^{13} \mathrm{~A}$ first mistake in decision making is the ignorance of the base rate (Ayres and Nalebuff, 2015) which is the most important factor in the theory of P: '[t]he prior probability, which must always be found before the method of pure induction can be usefully employed to support a substantial argument, is derived from considerations of analogy' (Keynes, 1921, p. 276), or more vividly 'telling a jury a likelihood ratio without a prior is akin to telling someone how many eggs to include in a cake recipe without telling them how much flour to use or the serving size' (Ayres and Nalebuff, 2015, p. 1500). The absence of the base rate is present also in the law when analogy (the other name for induction) is used in improper contexts. The base rate is constituted by all things decision-makers know but it does not constitute a decision in question (although it is very relevant for the latter's $P$ ). Popper assigned the utmost importance to this problem with his theory of falsifiability, by which 'universal statements are never derivable from singular statements, but can be contradicted by singular statements' (2002, p. 19). Singular observations should be used only to falsify possible general solutions, not to deduce any particular solution from them. ${ }^{14}$ Because the positive or the negative analogy deals with resemblances or differences between objects, for Keynes 'to reduce resemblances between the instances is the same thing as to increase the differences between them. Hence any increase in the negative analogy involves a reduction in the comprehensiveness of the characteristics in which all the instances resemble one another outside those covered by the generalisation' (Keynes, 1921, p. 262). The key to reinforce a positive argument is to increase known differences between instances: '[t]he object of increasing the number of instances arises out from the fact that we are nearly always aware of some difference between the instances...Every new instance may diminish the unessential resemblances between the instances and, by introducing a new difference, increase the Negative Analogy. For this reason, and for this reason only, new instances are valuable' (Keynes, 1921, p. 269).

A solution for legal science could be thus also to look for the negative when analogy or induction is used. The function of induction is to tell us not which predictions are right, but which predictions are indicated as wrong by our present knowledge: 'it is only when our inductive inferences are wrong we learn new things about the real world' (Jaynes, 2003, p. 326). Progress is the result of alertness to cases where the inductive method has led to inappropriate likelihoods. People up to a certain point ignore the fact that they did not (successfully) predict what would happen (although they later fall into confirmation bias with ease) and even amplify unwanted consequences by their erroneous thinking. The gist of Carroll's failure ("if you don't know where you are going, any road will get you there") can be seen in Ellenberg's "the missing

12 This approach is clearly wrong; it results in a more and more growing number of legal acts that cause the unintended consequences, administrative barriers, new institutions (without reforming the existent ones) etc.

13 Laws many times enact an obligation for an institution to assess risks (especially in Inspection Acts) without even mentioning (a rough frame) how risk could be assessed.

14 A legal principle stays as the valid principle regardless how many times is violated. 
bullet holes story": ${ }^{15}$ you can only find the weakest spot negatively by searching for missing bullets. People, on the other hand, think similarly, i.e. by exclusion of what they know (to get closer to things they do not know): '[t]hinking is a putting-aside, rather than a putting-in discipline, e.g., putting aside the tall grasses in order to isolate the trail into informative viewability. Thinking is frequency modulation for it results in tuning-out of irrelevancies as a result of definitive resolution of the exclusively tuned-in or accepted feed-back messages' pattern differentiatability' (Fuller, 1971, p. 121). Scientific systems are many times refuted negatively by experienced errors. Solutions are found after problems have been carefully addressed and ineffective (negative) methods excluded. The idea per se was known already in apophatic (negative) theology, which describes God by negation, that is speaking of God only in terms of what He is not (gr. apophanai, "to deny") rather than presuming to describe what God is (Theopedia, 2016).

It is surprising that in this regard (in its apophatic part) also Locke's Essay Concerning Human Understanding of 1689 was/is still unnoticed in legal decision-making. To him, liberty cannot be without thought, volition or will, while they can (non-freely) exist without liberty. Because liberty presupposes understanding and will, it cannot belong to the latter. Concerning a man's liberty, due to this inference, he is occupied with the further question of whether a man has free will. In respect of willing, he concludes that a man is not free: 'a man in respect of willing - when any action in his power is once proposed to his thoughts, as presently to be done - cannot be free [because] it is absolutely necessary that he will be the one or the other' (1999, p. 230). He concluded that will is determined by something outside itself, by uneasiness. Desire, as the uneasiness of the mind, determines the will and springs into action: '[t] he greatest positive good determines not the will, but present uneasiness alone...the greater good, though apprehended and acknowledged to be so, does not determine the will, until our desire, raised proportionally to it, makes us uneasy in the want of it. Another reason why it is uneasiness alone that determines the will, is this: because that alone is present and, it is against the nature of things, that what is absent should operate where it is not' (1999, p. 238). As he applied the method of exclusivist reasoning to liberty vis-à-vis the will and the latter vis-à-vis desire, he also uses it for the power to suspend the prosecution of any desire (which makes way for consideration). The mind has the power to suspend the execution and satisfaction of any of its desires. This is to him the source of liberty or so-called free will (Locke, 1999, p. 246). His reasoning is relevant for our ordinary understanding of legal decision-making, although more generally knowable structure of reality gave Spinoza in Ethics

15 The optimal protection of the U.S. army planes in WWII was about protecting the most vulnerable parts. An optimum amount of armour would be at the midpoint between not getting planes get shot down by enemy fighters and not making the plane too heavy, less manoeuvrable and less fuel efficient. The military wanted - in a common sense manner - to put more armour on the parts with the most numerous holes, when Abraham Wald (member of a classified statistical research group) asked: "Where are the missing holes"? The missing bullet holes were on the missing planes. The reason planes were coming back with fewer hits to the engine was that planes that got hit in the engine weren't coming back. Armour should be put on spots with no holes (Ellenberg, 2014). 
with his claim omnis determinatio est negatio (all determination is negation): all determination is possible because of positing unreal (finite) things as limitation/separation from the real (infinite) ones: 'as finite existence involves a partial negation, and infinite existence is the absolute affirmation of the given nature, it follows that every substance is necessarily infinite' (Descartes et al., 1974, p. 182). Although Descartes had a similar approach, ${ }^{16}$ Spinoza's infinite and uninterrupted Absolute was put on a higher level with Hegel's dialectics that involves interruptions in a continuous flow (Hegel is for lawyers known mostly with his Philosophy of Right), while an axiomatic mathematical confirmation of this "negative reasoning" was given by Kolmogorov. ${ }^{17}$

The apophatic, negative approach is also a solution to the most famous Wason selection task, the four-card problem in the study of deductive reasoning (Wason, 1968). A confirmation through negation is taught in legal schools as one of the first legal principles (neminem laedere- do no harm; in medicine it is known as primum non nocere - first, do no harm), so it is surprising to note that regulators or authorities usually do not use the elimination system of parts that are determined not to fit into a particular set. Although Merton popularised the notion of unintended (thus also unpredicted) consequences in social sciences (Merton, 1996), such consequences originate from Hume's "is-ought" problem of the (un)predictability of future events. For Taleb, a series of corroborative facts is not necessarily evidence (2010) and to prevent this naïve empiricism as Popper intuitively thinks, we can get closer to the truth using the negative instances, not by verification: '[y] ou know what is wrong with a lot more confidence than you know what is right' (Taleb, 2010). A theory is rational or empirical if it can be examined critically either in a direct way (if there are already known facts) or by examining/testing its (potentially negative) consequences. The reasoning here differs from Popper's, because along with a theory's de facto examination using the new and new hypothesis, we can also (only) predict/assume negative consequences without the hypothesis's examination if there are some predispositions present that allow predictions. There are fields and/or conditions in which prediction can arise based on 'the necessity of scheduling and coordinating our actions...statistical regularities...the knowledge of the causal regularities of nature ... [and] the knowledge of causal regularities in social life' (Maclntyre, 2007, pp. 102-103).

Legal science has placed too much emphasis on positive results, i.e. what the laws, case-law, adjudications and practices are, while their negative sides should not be seen only as failures but as a source of valuable information: what is not the law, case-law, adjudication and practices is as valuable as their positive counterparts: only when grouped together they represent a whole.

16 I must not imagine that I do not apprehend the infinite by a true idea, but only by the negation of the finite (Descartes, Spinoza, \& Leibniz, 1974, p. 137).

17 He started the modern axiomatic foundations of probability theory with the first axiom: $\mathfrak{F}$ is a field of sets. A system of sets is called a field if the sum, product of and difference between two sets of the system also belong to the same system. The set $E-A$, which is the complement of $A$, is denoted by $\sim A(\sim$ denotes negative) (Kolmogorov, 1956, p. 2). From $A+\sim A=E$, it follows that $P(\sim A)=1-P(A)$. What we do not know and what we know represents a principle of unity. What we do not know can be indirectly assumed through what we know. 
A draft general rule can be tested with increasingly remote consequences in the form of negative potentiality: we can more easily imagine negative consequences (what could happen in a black scenario) than what will certainly happen. Options are substitutes for knowledge; they give us a possibility to choose an option that is ex ante the least harmful or ex post the most beneficial in a light of gained experience (the intelligence effect of trial and error in Pasteur's notion of chance that favours only the prepared mind). Lawyers (states) could try to think through the (negative ${ }^{18}$ ) consequences of the proposed solutions and/or present decisions based on a certain potency that arises due to complexity itself or consequences that increase twice or three times of a projected number and in such way obtain predictions and prepare future actions. In the future, we could also look through absent things (un/ wanted consequences and/or alternative scenarios) and their magnitudes. If we do not know whether something will happen or not, it is better to concentrate on those potential consequences that would be most harmful to us. From here, we can calculate the $P$ of events and propose relevant measures. This could also be called "Black Swan logic", which makes what you do not know far more relevant than what you do know (Taleb, 2010). To solve things, we must focus on what we do not know, i.e. to focus on potential harmful extremes; we can get closer to the truth through negative instances rather than by (impossible) verification. We need to administer (absent) consequences.

\section{Conclusion}

The behaviour of integral aggregate (legal and other) systems cannot be determined with the classical regulatory methods. If the only two alternatives or hypotheses regulators admit are good/bad or legal/illegal, the whole rich and enormous structure of the living world (and soft law also) is taken out as "evidence" on the account of diversity with its numerous possibilities and/ or real processes that work outside the human binary alternatives. Induction, analogy and causality can be better embraced if we accept the world of signs that transfer to us information about unwanted (but known) consequences. A binary stance should be replaced with a colourful scale of weights. Their numerical exposition is represented in $P$, which is present also in a search for the negative. The problem of induction can be reduced negatively through the reduction of what we know to what we have signs. People can not only use their liberty or free will when they consider the problem's positive and negative sides, but they reason more objectively when problems' elements are determined negatively. The more there are, the more the positive side can also be determined. The concepts of the mutual independence of two or more multiplicative events and additive dependent events are the sine qua non for $P$ that from a set of fields (the larger the better) predict future events. What is missing in common sense reasoning is precisely all the "missing" signs

18 In the absence of known consequences, it is easier to imagine what should not happen and the first rule is not to do harm to other people - in medicine this is known as Hippocrates's Primum non nocere ("first do no harm"), while the precepts of the Law are to live honestly, not to injure another and to give to each one that which belongs to him ("Iuris præcepta sunt hæc: honeste vivere, neminem laedere, suum cuique tribuere-Institutes, Bk. 1, title 1). 
that disconfirm our prior belief and confirm the same result from different perspectives. And the same is true for legislation, because it usually does not imitate the adaptable, complex (human) organisms that predict future scenarios of what could happen.

As regards RQ - $P$ can be embedded in legislation by posting future (negative) scenarios and to them appropriate actions. Legislation can be more adaptable to changes in environment and be at the same time in accordance with public values through the non-stop feedbacks, (re)organisations and (re)arrangements of elements. In this way control can be constantly (re)acquired over new situations that emerge during a change of different conditions or appear during an implementation of rules - if we know what our goals/scenarios are, i.e. what we do not want. ${ }^{19}$ The "emergent idea of legislaton" is that if you want goals, focus on a system in which goals are achieved, i.e. focus on processes, their interactions, build the real-time feedback loops and establish transparency for all stakeholders and citizens to be able to tell you what they do not want. Despite all efforts, final goals can be known today as unwanted consequences. On a general (regulatory) level a system is needed in which information asymmetries are minimised in a quick manner (this include also the moral hazard and human fallibility), and this paper gives the solution: it is a system that accommodates/realigns its actions according to detected signs that fit into unwanted scenarios.

19 E.g. the plastic and other pollution, alcoholism among young people, fatal accidents, an increase of a certain type of disease - what a country should do in the scenario 1 (10\% increase), scenario 2 (20\% increase), scenario 3 (30\% increase), etc.? Regardless of taking causality outside consideration each country can in the present time determine measures for future scenarios; when they come, known measures can be applied without loosing a precious time. 


\section{References}

Alexander, L. and Sherwin, E. (2008). Demystifying Legal Reasoning. Cambridge University Press.

Ayres, I. and Braithwaite, J. (1995). Responsive Regulation: Transcending the Deregulation Debate. New York, Oxford: Oxford University Press.

Ayres, I. and Nalebuff, B. (2015). The rule of probabilities: a practical approach for applying Bayes' rule to the analysis of DNA evidence. Stanford Law Review, 67(6), pp. 1447-1503.

Baron, J. (1998). Judgment Misguided: Intuition and Error in Public Decision Making. Oxford: Oxford University Press.

Beecher-Monas, E. (2007). Evaluating Scientific Evidence: An Interdisciplinary Framework for Intellectual Due Process. Cambridge: Cambridge University Press.

Black, J. (2012). The Role of Risk in Regulatory Processes. In R. Baldwin, M. Cave and M. Lodge, eds., The Oxford Handbook of Regulation. Oxford, New York: Oxford University Press, pp. 302-348.

Brest, P. and Krieger, L. H. (2010). Problem Solving, Decision Making, and Professional Judgment: A Guide for Lawyers and Policymakers. New York: Oxford University Press.

Carnap, R. (1966). Philosophical Foundation of Physics: An Introduction to the Philosophy of Science. New York: Basic Books.

Carrier, R. (2012). Proving History: Bayes's Theorem and the Quest for the Historical Jesus. Amherst, N.Y: Prometheus Books.

Chiu, I. H.-Y. (2015). Regulating (From) the Inside: The Legal Framework for Internal Control in Banks and Financial Institutions. Oxford, Portland: Hart Publishing.

Cicero. (2008). The Nature of the Gods. (P. G. Walsh, Trans.). Oxford, New York: Oxford University Press.

Comte, A. (1998). Comte: Early Political Writings. (H. S. Jones, Ed.). Cambridge: Cambridge University Press.

Cziko, G. (2000). The Things We Do: Using the Lessons of Bernard and Darwin to Understand the What, How, and why of Our Behavior. Cambridge: MIT Press.

Descartes, R., Spinoza, B. de and Leibniz, G. W. V. (1974). The Rationalists: Descartes: Discourse on Method \& Meditations; Spinoza: Ethics; Leibniz: Monadolo gy \& Discourse on Metaphysics. New York: Anchor Books.

Dworkin, R. (1978). Taking Rights Seriously. Cambridge: Harvard University Press.

Dwyer, D. (2008). The Judicial Assessment of Expert Evidence. Cambridge: Cambridge University Press.

Edwards, W., Jr, R. F. M., and Winterfeldt, D. von. (2007). Advances in Decision Analysis: From Foundations to Applications. New York: Cambridge University Press.

Ellenberg, J. (2014). How Not to Be Wrong: The Power of Mathematical Thinking. New York: Penguin USA.

Evidence | Define Evidence at Dictionary.com. (2016). At<http://www.dictionary. com/browse/evidence?s=t>, accessed 15 March 2016.

Finkelstein, M. O. and Fairley, W. B. (1970). A Bayesian Approach to Identification Evidence. Harvard Law Review, 83(3), pp. 489-517. 
Finkelstein, M. O. and Fairley, W. B. (1971). The Continuing Debate over Mathematics in the Law of Evidence: A Comment on 'Trial by Mathematics'. Harvard Law Review, 84(8), pp. 1801-1809.

Fisher, G. (2012). Evidence (3 edition). New York: Foundation Press.

Fuller, R. B. (1971). No More Secondhand God. New York: Doubleday \& Co., Inc. Garner, B. A. (Ed.) (2004). Black's Law Dictionary. St. Paul, MN: Thomson West. Gigerenzer, G. (2003). Reckoning with Risk: Learning to Live with Uncertainty. London: Penguin UK.

Gigerenzer, G., Todd, P. M. and Group, A. R. (2000). Simple Heuristics That Make Us Smart. New York: Oxford University Press.

Good, I. J. (1950). Probability and the Weighing of Evidence. London: Charles Griffin \& Co. Limited.

Good, I. J. (1983). Good Thinking: The Foundations of Probability and Its Applications. Minneapolis: University of Minnesota Press.

Gunningham, N., Grabosky, P. N. and Sinclair, D. (1998). Smart Regulation: Designing Environmental Policy. Oxford: Oxford University Press.

Hacking, I. (1990). The Taming of Chance. Cambridge: Cambridge University Press.

Hacking, I. (2001). An Introduction to Probability and Inductive Logic. Cambridge: Cambridge University Press.

Hacking, I. (2006). The Emergence of Probability: A Philosophical Study of Early Ideas about Probability, Induction and Statistical Inference. Cambridge University Press.

Hood, C., Rothstein, H. and Baldwin, R. (2001). The Government of Risk: Understanding Risk Regulation Regimes. Oxford: Oxford University Press.

Hudson, B. (2003). Justice in the Risk Society: Challenging and Re-affirming 'Justice' in Late Modernity. SAGE.

Hume, D. (2009). A Treatise of Human Nature. Auckland: The Floating Press.

Jaynes, E. T. (2003). Probability Theory: The Logic of Science. Cambridge University Press.

Jeffreys, H. (1998). Theory of Probability. Oxford Oxfordshire, New York: Oxford University Press.

Kafka, F. (2004). Proces. Ljubljana.

Kahneman, D. (2013). Thinking, Fast and Slow. New York: Farrar, Straus and Giroux.

Kant, I. (2004). Immanuel Kant: Prolegomena to Any Future Metaphysics: That Will Be Able to Come Forward as Science: With Selections from the Critique of Pure Reason. Cambridge: Cambridge University Press.

Keynes, J. M. (1921). A Treatise on Probability. London: MacMillan and Co.

Kolmogorov, A. N. (1956). Foundations of the Theory of Probability. New York: Chelsea Publishing Company.

Leibniz, G. W. (1988). Leibniz: Political Writings. Cambridge University Press.

Leibniz, G. W. F. von. (1996). Leibniz: New Essays on Human Understanding. Cambridge University Press.

Locke, J. (1999). An Essay Concerning Human Understanding. Pennsylvania: The Pennsylvania State University. 
Maclntyre, A. C. (1978). Against the Self-images of the Age: Essays on Ideology and Philosophy. Notre Dame: University of Notre Dame Press.

Maclntyre, A. C. (2007). After Virtue: A Study in Moral Theory. Indiana: University of Notre Dame Press.

Marx, K. (1976). The German Ideology: Including Theses on Feuerbach and Introduction to The Critique of Political Economy. Amherst, N.Y: Prometheus Books.

Merton, R. K. (1936). The Unanticipated Consequences of Purposive Social Action. American Sociological Review, 1(6), 894-904.

Merton, R. K. (1996). On Social Structure and Science. Chicago: University of Chicago Press.

OECD. (2009). Regulatory Impact Analysis: A Tool for Policy Coherence. OECD Publishing.

OECD. (2014). The Governance of Regulators, OECD Best Practice Principles for Regulatory Policy. OECD Publishing.

OECD. (2017). Systems Approaches to Public Sector Challenges: Working with Change. Paris: OECD Publishing.

Oxford Dictionaries. (2016). Cataphatic - definition of cataphatic in English from the Oxford dictionary. At <http://www.oxforddictionaries.com/definition/ english/cataphatic>, accessed 2 March 2016.

Palmer, A. (1998). Principles of evidence. Newport: Cavendish Publishing.

Pečarič, M., Jovanović, T., Kozjek, T. and Greif, M. (2015). Objektivnost sprejemanja oblastnih odločitev: projekt kategorije A. Ljubljana: Fakulteta za upravo.

Popper, K. (2002). The Logic of Scientific Discovery. London; New York: Routledge.

Popper, K. R. (1962). Conjectures and Refutations: The Growth of Scientific Knowledge. New York, London: Basic Books.

Rawls, J. (2005). A Theory of Justice. Cambridge, Mass: Belknap Press.

Ridder, J. (2007). Factors for legal quality of administrative decision-making. In K. J. Graaf, J. H. Jans, A. T. Marseille, and J. Ridder, eds., Quality of Decisionmaking in Public Law: Studies in Administrative Decision-making in the Netherlands. Groningen: Europa Law Publishing, pp. 31-51.

Sieber, S. (1981). Fatal Remedies: The Ironies of Social Intervention. New York, London: Plenum Press.

Taleb, N. N. (2010). The Black Swan: The Impact of the Highly Improbable Fragility. New York: Random House Publishing Group.

Theopedia. (2016). Negative theology | Theopedia. At <http://www.theopedia. com/negative-theology>, accessed 2 March 2016.

Tribe, L. H. (1971). Trial by Mathematics: Precision and Ritual in the Legal Process. Harvard Law Review, 84(6), pp. 1329-1393.

Tversky, A. and Kahneman, D. (1974). Judgment under Uncertainty: Heuristics and Biases. Science, 185(4157), pp. 1124-1131.

Wason, P. C. (1968). Reasoning about a rule. Quarterly Journal of Experimental Psychology, 20(3), pp. 273-281.

Wittgenstein, L. (1986). Philosophical Investigations. Oxford: Basil Blackwell. 